\title{
THE CHARACTERISTICS OF SAGO FROND SAP FROM TWO SELECTED GROWTH STAGES; ANGKAT PUNGGUNG AND UPONG MUDA PALMS
}

\author{
Nurazureen Matnin ${ }^{1 a}$, Dayang Salwani Awang Adeni ${ }^{2 a^{*}}$, Muhammad Norhelmi \\ Ahmad $^{3 a}$ and Nurashikin Suhailita
}

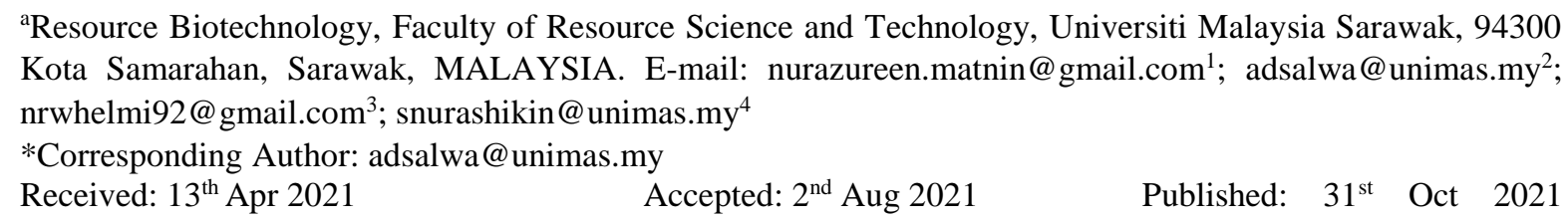

DOI: https://doi.org/10.22452/mjs.vol40no3.4

\begin{abstract}
Sago frond is produced in abundance upon harvesting of the sago palms for starch extraction, hence need to be utilized and developed into beneficial products. In this study, the sap which contains sugars and starch is obtained by roller crushing the skinned frond for use as fermentation medium. Fronds from two selected growth stages (namely Angkat punggung and Upong muda) and two different positions within the rosette (inner and outer circle) of the sago palm were studied. Based on the results, the outer circle frond of Upong muda palm gave the highest volume of sap at $290 \mathrm{~mL} / \mathrm{kg}$ which equivalent to 1600 $\mathrm{mL} /$ frond. On top of that, sago frond sap has an acidic $\mathrm{pH}$, with glucose as major sugar component and contained various kinds of minerals like calcium, potassium and manganese. All fronds from two selected growth stages contain glucose between 28-68 g/L and xylose 21-29 g/L, respectively. After 21 days of storage, it can be concluded that the amount of reducing sugars and starch in most samples obtained from two selected growth stages decreased slightly from the original. Subsequently after this study, both fresh and stored sago frond sap can be used as a fermentation substrate without any pre-treatment or modification.
\end{abstract}

Keywords: Angkat punggung, fermentation, starch, sugar, Upong muda.

\section{INTRODUCTION}

Sago is one of the important commodities which contribute to the economic value in our countries. In Malaysia, the state of Sarawak has the largest sago plantation area which is about 54,000 hectares (DoS, 2015). Bujang (2014) pointed out that the sago palm is the only commodity that able to grow in peat soil which occupies around $75 \%$ of coastal plains and lowland river basins in Sarawak. The growth of sago palm on humid peat soil reduces farmland competition with other crops which makes sago palm better than other cash crops. Nowadays, the starch made from sago are marketable and provide a regular cash flow to the sago farmers. However, sago palm takes years, up to ten years to reach maturity stages before harvested (Bujang, 2014). Throughout the maturation period, farmers have to wait up to ten years to earn income from the harvested sago palm. As one of the potential biomass, the utilization of sago frond can provides benefits to sago farmers and generate new passive income for them in a short time. 
Sago frond can be a leafy waste, disposed after harvesting of sago palms for starch extraction. According to Ahmad et al. (2016), about 500 palms are harvested daily in Mukah, Sarawak and at about 15 fronds/palm, at least 7,500 fronds are discarded, each day. Moreover, approximately 60,000-65,000 tons of sago starch exports annually by the state of Sarawak (DoS, 2012) causing a lot of biomass including sago frond waste produced. Sago frond is a potential waste, but also a valuable resource if processed to produce sugars or other by-products. It is also a lignocellulosic material which comprise primarily of cellulose, hemicellulose and lignin (Adeni et al., 2018), and if left on the plantation floor, these fronds can potentially cause serious environmental issues due to their slow degradability rate. Thus, to address these issues, we focused our research on characterising the sugar, starch and mineral contents of the sap extracted from the sago frond in order to develop it into valuable by-product.

The potential of frond sap as a fermentation substrate is high due to free sugar content, which can be used directly for fermentation without pre-treatment and any modification. Zahari et al. (2012) in his study revealed that lignocellulosic wastes which mainly comes from agricultural wastes are the best replacement for fermentation substrate as these wastes are abundant, non-edible and involved cost reducing process. The carbon sources present in agricultural residues can eliminate cost of the substrate needed for fermentation, making it ideal as a fermentable substrate. As an alternative for fermentation process, the chemical composition of sago frond sap needs to be studied in order to assess its suitability as a fermentation substrate.

Therefore, this study aimed to characterise biochemical (volume, mineral contents, sugars, starch) contents of frond sap from two selected growth stages (Angkat punggung and Upong muda) and two different positions within the rosette (inner and outer circle) of the sago palm. Frond from younger palms; Angkat punggung and Upong muda was selected as it is the stages where the starting of trunk and frond formation of palm (Jong, 1995). The palm growth was chosen depending on which part of palms could produce new valuable by-products in a short period of time.

Moreover, Adeni et al., (2018) studied that sugar content in enzymatic hydrolysed dried frond differ significantly at different growth stages, with the adolescent frond exhibited the highest sugar recovery $(8.85 \%)$ due to its high cellulose content. The previous study clearly showed that the sugars content in sap at different growth stages also may vary. Among the specified growth stages, the sap containing the most sufficient sugar for fermentation must be identified because it is one of important criteria to boost ethanol production performance. All frond sap in this study was kept at $-20^{\circ} \mathrm{C}$ for storage analysis within 21 days. Subsequently after this study, the most suitable frond sap from selected growth stages of sago palm that can be used as a fermentation substrate was determined.

\section{MATERIALS AND METHODS}

\subsection{Sago Fronds}

Sago fronds obtained from sago plantation in Kota Samarahan, Sarawak were used as main raw material in this study. Two types of fronds at different positions within the rosette; inner circle frond (third frond from centre) and outer circle frond (the outmost frond from centre) were collected from two selected sago palm at different ages (Jong, 1995); 
4-5 years (Angkat punggung) and 6-7 years (Upong muda) during the pruning process as shown in Figure 1. The palm from first growth stage, Sulur (1-4 years) palm was not chosen as it is too immature, with only rosette stage formation and no visible trunk form during this stage. The collection of sago fronds during sampling process involved $18-20$ palms.

\subsection{Preparation of Sago Frond Sap}

After leaves were removed, skinned fronds were cut longitudinally into small size to ensure that the size of fronds is suitable to be put into roller press machine. The extracted sap was filtered and prepared without any pre-treatment or modification. Total volume of sap and weight of frond at two different growth stages were recorded. The fresh sap obtained was analysed promptly in order to determine the composition of major sugar components. Then, all extracted sap were stored at $-20^{\circ} \mathrm{C}$ and collected every 48 hours for 21 days in order to analyse the $\mathrm{pH}$, total reducing sugar and starch contents. The storage of sap was conducted in order to ensure that the sap extracted on the harvesting day need to be processed immediately or conversely. It is kept for 21 days to evaluate the yield of sugars while also observing the physical changes that occur in the sap.

\subsection{Determination of Sugar Component}

High Performance Liquid Chromatography (HPLC) (Shimadzu, Japan) was used to determine type of sugars produced by sago frond sap. The HPLC was integrated with Refractive Index (RID-10A) detector with a column of prominence CTO-20A and $0.005 \mathrm{M}$ $\mathrm{H}_{2} \mathrm{SO}_{4}$ was used as the mobile phase, with flow rate of $0.8 \mathrm{ml} / \mathrm{min}$ at $60^{\circ} \mathrm{C}$ (Adeni et al., 2013).

\subsection{Analyses of Mineral Contents}

Mineral contents of the sago frond sap were analyzed by the Sarawak Plantation Laboratory (SPLAB), Kuching, Sarawak. Some minerals are known to work as a growth booster in fermentation; hence presence of these minerals will be beneficial if the sap is to be used as substrate for the production of ethanol.

\subsection{Determination of $\mathrm{pH}$}

The $\mathrm{pH}$ of sago frond sap at different growth stages was taken every 48 hours and determined using $\mathrm{pH}$ meter (Bante Instrument, China). All the tests were performed triplicate.

\subsection{Total Reducing Sugar Analysis}

Total reducing sugar was determined according to the Dinitrosalicylic acid (DNS) method. Procedure from Miller (1959) was adopted in this study with slight modification. Sago frond sap was mixed with DNS reagent. Then, the mixture was heated in boiling water for about five to seven minutes and cooled in cold water. The absorbance of the reaction mixture was observed by using UV mini1240v Spectrophotometer (Shimadzu, Japan) at $575 \mathrm{~nm}$ wavelength. The reducing sugar content and sugar conversion from sago frond sap were calculated.

\subsection{Starch Content Analysis}

The starch content of sago frond sap was determined by using iodine starch colorimetric method (Nakamura, 1981). The reaction mixture of sago frond sap, iodine solution and distilled water was mixed in a test tube. Then, the absorbance of reaction mixture was analyzed by using UV mini-1240v Spectrophotometer (Shimadzu, Japan) at $590 \mathrm{~nm}$ wavelength. 
Total starch content of sago frond sap was calculated based on the standard curve of starch plotted.

\subsection{Statistical Analysis}

All data collected during experiment were compared and analysed by using One Way ANOVA. LEAD Technologies, MINITAB version 17 was used to perform statistical analysis.

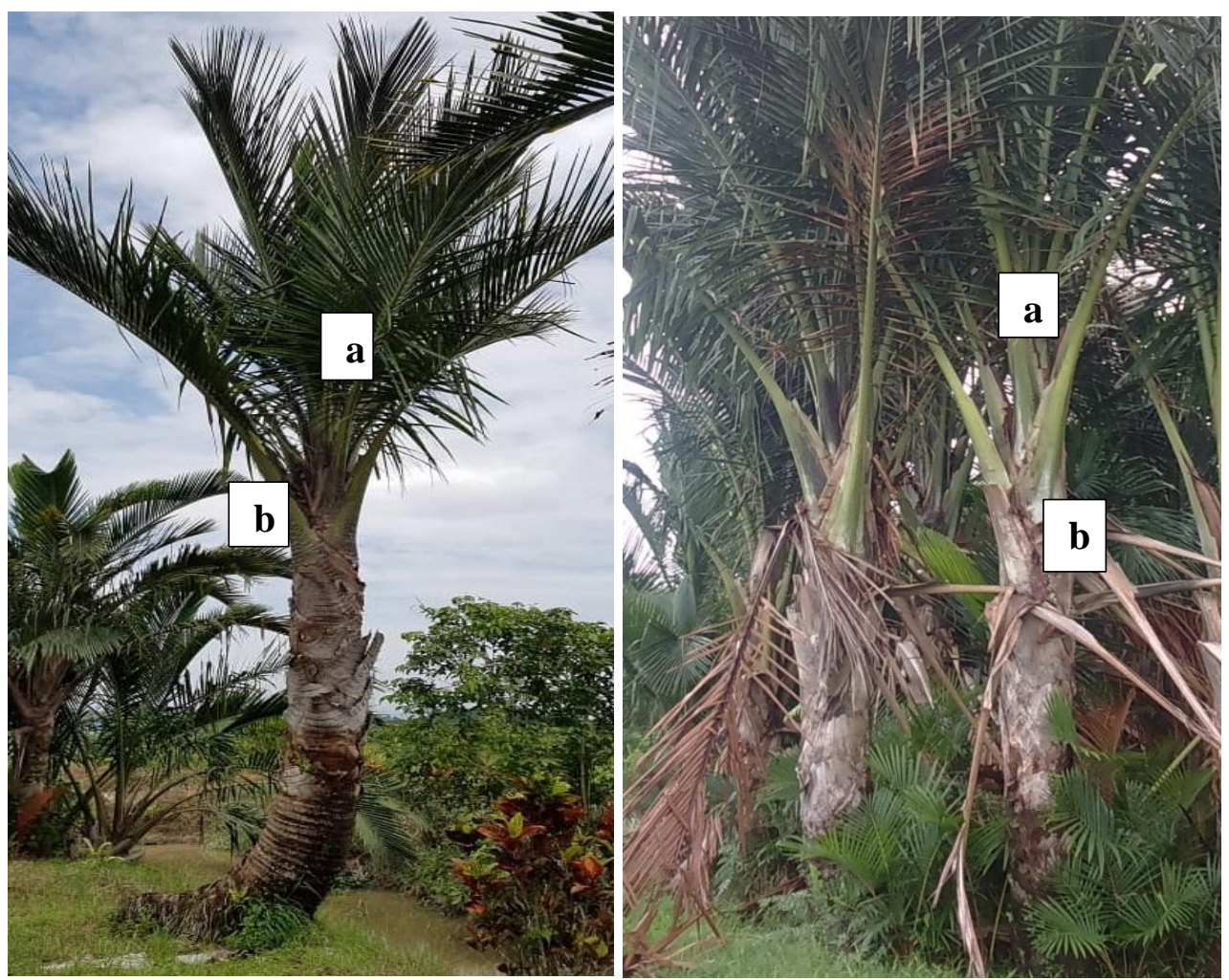

Figure 1. Two types of fronds; (a) inner circle and (b) outer circle fronds were collected from two different sago palm at different ages; 4-5 years (Angkat punggung, left) and 6-7 years (Upong muda, right)

\section{RESULTS AND DISCUSSION}

\subsection{Total Volume of Sago Frond Sap}

Total volume of sap extracted from sago fronds based on two selected growth stages; Angkat punggung (inner and outer circle) and Upong muda (inner and outer circle) are recorded with different weight of fronds ( $1 \mathrm{~kg}$ and one frond) as presented in Table 1.

Among all the fronds selected, outer circle fronds from Upong muda palm yield the largest volume of sago frond sap. It was observed that outer circle fronds from
Upong muda palm produced the highest volume of sap, which is $293 \mathrm{~mL} / \mathrm{kg}$. Similarly, total volume of sap extracted from one sago frond show the same trend by showing that outer circle frond from Upong muda palm have the highest sap (1666 $\mathrm{mL} /$ frond) and it lowest (451 $\mathrm{mL} /$ frond) by inner circle frond from Angkat punggung palm. In comparison to other selected growth stages, it can be concluded that the best frond (outer circle from Upong muda) weighs about $5-6 \mathrm{~kg}$ and it was estimated around $1500 \mathrm{~mL}$ of sap can be extracted from here (approximate ratio 1 frond: 1.5 litre sap). At between 10 to 15 fronds per palm, 
a minimum of 18 litre sap per palm can be obtained, or total of 9,000 litres from a daily harvest of 500 palms in the Mukah District in Sarawak.

Increase in the weight and diameter of fronds had significantly increased the volume of frond sap extracted. This could be because the influence of fronds size is noticeable as the larger frond was observed to extract more volume of sap. Outer circle frond from both Angkat punggung and Upong muda palm shows the largest diameter of frond. Besides, the diameter of sago frond is increasing with the increasing of number of fronds and plant age (Flach, 1997). These indicated that the ages of sago fronds and palms are the main factor that affects the volume of sago frond sap.

The other possibility that may affect the volume of sap is moisture content of sago fronds itself. The result obtained was also correlate with the previous studies on oil palm fronds (Kosugi et al., 2010), which reported that the larger size of fronds contained a high level of moisture, thus indicating the presence of a large quantity of sap.

Table 1. Total volume of sap extracted from different sago fronds.

\begin{tabular}{|c|c|c|c|c|}
\hline \multirow{2}{*}{\multicolumn{2}{|c|}{$\begin{array}{l}\text { Growth stages of } \\
\text { frond }\end{array}$}} & \multirow{2}{*}{$\begin{array}{l}\text { Total volume of } \\
\text { sap extracted } \\
(\mathrm{mL}) \text { from } 1 \mathrm{~kg} \\
\text { frond }\end{array}$} & \multicolumn{2}{|c|}{ One sago frond } \\
\hline & & & $\begin{array}{l}\text { Weight of sago } \\
\text { frond (g) }\end{array}$ & $\begin{array}{c}\text { Total volume of } \\
\text { sap extracted }(\mathrm{mL})\end{array}$ \\
\hline \multirow{2}{*}{$\begin{array}{c}\text { Angkat } \\
\text { punggung } \\
\text { (4-5 years) }\end{array}$} & $\begin{array}{l}\text { Inner } \\
\text { circle }\end{array}$ & $226.67^{\mathrm{c}} \pm 4.41$ & $1996.33^{c} \pm 77.45$ & $451.67^{\mathrm{c}} \pm 8.82$ \\
\hline & $\begin{array}{l}\text { Outer } \\
\text { circle }\end{array}$ & $270.00^{\mathrm{b}} \pm 2.89$ & $3039.67^{b} \pm 134.71$ & $845.00^{\mathrm{b}} \pm 7.64$ \\
\hline \multirow{2}{*}{$\begin{array}{c}\text { Upong } \\
\text { muda } \\
\text { (6-7 years) }\end{array}$} & $\begin{array}{l}\text { Inner } \\
\text { circle }\end{array}$ & $280.00^{\mathrm{ab}} \pm 2.89$ & $3163.33^{b} \pm 166.04$ & $876.67^{\mathrm{b}} \pm 9.28$ \\
\hline & $\begin{array}{l}\text { Outer } \\
\text { circle }\end{array}$ & $293.33^{\mathrm{a}} \pm 1.67$ & $6013.67^{\mathrm{a}} \pm 95.93$ & $1666.67^{\mathrm{a}} \pm 11.67$ \\
\hline
\end{tabular}

\subsection{Total Major Free Sugars in Sago Frond Sap}

The composition of major type of sugars in sago frond sap is presented in Table 2. The sago frond sap was analysed without any pre-treatment or modification.

Based on the result, HPLC sugar analysis revealed that glucose and xylose were free sugar components that can be found in the sago frond sap, whereas glucose was found to be the major sugar in all parts. The inner circle frond of Upong muda exhibited the highest amount of glucose $(68 \mathrm{~g} / \mathrm{L})$ and xylose $(29 \mathrm{~g} / \mathrm{L})$ compared to other fronds. It can be concluded that both growth stages (Angkat punggung and Upong muda) contain a significant amount of glucose and xylose, approximately between $28-68 \mathrm{~g} / \mathrm{L}$ and 21 $29 \mathrm{~g} / \mathrm{L}$, respectively.

These results indicated that sago frond sap contains high amount of fermentable sugars; glucose and xylose $(4.9-9.8 \%)$ which can be used directly for fermentation without any modification or 
pre-treatment. Overall, sago frond sap contains high amount of glucose, approximately between $28-68 \mathrm{~g} / \mathrm{L}$, which significantly higher than enzymatic hydrolysis dried sago frond, $15-20 \mathrm{~g} / \mathrm{L}$ (Ahmad et al., 2016). Dried solid sago frond is the whole frond that has been dried, ground into powder form and undergo enzymatic hydrolysis process for the glucose production. It is not a biomass resulting from sap extraction. Meanwhile, the main material in this research, sago frond sap naturally contains glucose without go through pre-treatment process or involves addition of enzyme. It means that glucose in frond sap can be used as a carbon source during fermentation process. All these are excellent criteria for largescale ethanol or lactate fermentation.

Table 2. Composition of major free sugar components in sago frond sap.

\begin{tabular}{|c|c|c|c|}
\hline \multicolumn{2}{|c|}{ Growth stages of frond } & Glucose (g/L) & Xylose (g/L) \\
\hline $\begin{array}{c}\text { Angkat punggung } \\
\text { (4-5 years) }\end{array}$ & $\begin{array}{l}\text { Inner circle } \\
\text { Outer circle }\end{array}$ & $\begin{array}{l}40.00^{\mathrm{b}} \pm 0.62 \\
27.54^{\mathrm{c}} \pm 1.87\end{array}$ & $\begin{array}{l}23.73^{b} \pm 0.31 \\
20.67^{b} \pm 0.68\end{array}$ \\
\hline $\begin{array}{l}\text { Upong muda } \\
\text { (6-7 years) }\end{array}$ & $\begin{array}{l}\text { Inner circle } \\
\text { Outer circle }\end{array}$ & $\begin{array}{l}67.74^{\mathrm{a}} \pm 0.27 \\
44.71^{\mathrm{b}} \pm 0.78\end{array}$ & $\begin{array}{c}29.42^{\mathrm{a}} \pm 1.78 \\
24.93^{\mathrm{ab}} \pm 0.43\end{array}$ \\
\hline
\end{tabular}

\subsection{Total Minerals Content of Sago Frond Sap}

Table 3 represents the lists of minerals content; nitrogen, phosphorus, potassium, calcium, magnesium, boron, copper, zinc, iron and manganese contained in inner circle frond sap of Upong muda palm. Since sap from inner circle frond of Upong muda exhibited the highest fermentable sugars; glucose and xylose compared to other selected growth stages palm, it was analysed for mineral contents analysis in order to minimizing the cost for sample testing.

Calcium, potassium, manganese, magnesium and phosphorus are contained at higher concentration compared to other minerals. In contrast, nitrogen and copper were analysed as trace element in sago frond sap. It means that these trace elements contained very low concentration or amount in sago frond sap compared to other minerals. The minerals content detected in sago frond sap is expected to be a good medium for the growth of microbe such as yeast and then enhance the fermentation process.

Sago frond sap contains high amount of minerals $(\mathrm{Ca}, \mathrm{K}, \mathrm{Mn}, \mathrm{Mg}$ and $\mathrm{P}$ ) which is useful in ethanol and kojic acid fermentation. Analyses of the frond sap shows that it contains high amount of calcium and magnesium which is suitable for supplementation of ethanol production. Calcium supports the yeast cell growth during fermentation as it involved in membrane structure and for yeast flocculation (Russell, 2003). In separate report following this studies, it has been shown that approximately $25 \mathrm{~g} / \mathrm{L}$ ethanol is produced from sugars in sago frond sap after two days of fermentation. In addition, high amount of phosphorus in frond sap is useful because phosphate is an important nutrient that supports the growth of most fungi and enhances the kojic acid production during fermentation (Mohamad et al., 2010). 
Table 3. Total mineral content in the inner circle frond sap of Upong muda palm.

\begin{tabular}{cc}
\hline Mineral Content & Content (ppm) \\
\hline Nitrogen (N) & TRACE \\
Phosphorus (P) & 100 \\
Potassium (K) & 800 \\
Calcium (Ca) & 1200 \\
Magnesium (Mg) & 200 \\
Boron (B) & 2 \\
Copper (Cu) & TRACE \\
Zinc (Zn) & 2 \\
Iron (Fe) & 3 \\
Manganese $(\mathrm{Mn})$ & 213 \\
\hline
\end{tabular}

*Data are presented from oven dried sample as parts per million (ppm)

\section{4 pH of Stored Sago Frond Sap}

Table 4 shows the $\mathrm{pH}$ analysed on all frond sap stored at $-20^{\circ} \mathrm{C}$. The sap was collected every 48 hours for 21 days.

These results indicated that all sago frond sap at two different growth stages has an acidic $\mathrm{pH}$ ranging from 4.85 to 5.1. After 21 days of storage, the $\mathrm{pH}$ value showed a decreasing trend in all frond sap at different growth stages. It can be concluded that the acidity of the frond sap increased slightly during the storage. In addition, this could be due to the low temperature $\left(-20^{\circ} \mathrm{C}\right)$ of storage which may inhibited the growth of microorganism in the frond sap. However, there is no significant difference observed in
$\mathrm{pH}$ of frond sap on Day 1 and Day 21. It showed that the $\mathrm{pH}$ of sap does not give different results after being stored for 3 weeks.

All sago frond sap was stored at $-20^{\circ} \mathrm{C}$ before further analysis to avoid any spoilage and microbiological contamination on the sap. After 21 days, the colour and condition of all sap stored at $-20^{\circ} \mathrm{C}$ remains unchanged. In this study, the sap that was not stored at room temperature to avoid the growth of mold, unpleasant odour, spoiled after few days of storage. Similar study performed by Singh et al. (2014) mentioned that sugarcane juice stored at $30^{\circ} \mathrm{C}$ spoiled after 24 hours due to the increasing number of microbial count (bacteria, yeast, fungi) during storage.

Table 4. $\mathrm{pH}$ of sago frond sap observed after 21 days interval.

\begin{tabular}{cccc}
\hline \multicolumn{2}{c}{ Growth stages of frond } & Initial pH (Day 1) & Final pH (Day 21) \\
\hline $\begin{array}{c}\text { Angkat punggung } \\
(4-5 \text { years })\end{array}$ & Inner circle & $4.85^{\mathrm{c}}$ & $4.70^{\mathrm{c}}$ \\
\hline $\begin{array}{c}\text { Upong muda } \\
\text { (6-7 years) }\end{array}$ & Inner circle & $5.05^{\mathrm{a}}$ & $4.94^{\mathrm{a}}$ \\
\hline
\end{tabular}

*Means that do not share a letter are significantly different at $\mathrm{p}<0.05$ 


\subsection{Effects of Storage on the Reducing Sugar from Sago Frond Sap}

In this study, the total reducing sugar of sago frond sap at two selected growth stages; Angkat punggung palm (inner and outer circle fronds) and Upong muda palm (inner and outer circle fronds) was analysed. The sap was kept at $-20^{\circ} \mathrm{C}$ during storage and analysed for every 48 hours within 21 days. The total reducing sugar and percentage loss/gain of all saps at different growth stages was presented in Table 5.

Based on the result, it was observed that sap of inner circle frond from Upong muda palm shows the highest initial reducing sugar with an average of $65 \mathrm{~g} / \mathrm{L}$. However, the total reducing sugar of some sap showed a decreasing trend after 21 days of storage. Percentage loss of total reducing sugar in Angkat punggung; outer circle and Upong muda; inner and outer circle frond after storage are $34 \%, 15 \%$ and $24 \%$ respectively.

The low temperature during storage may deactivated the role of microbe to degrade and convert into glucose. During the storage, the concentration decreased slightly after 21 days. This suggests that the decrease of sugars is mainly caused by deactivation of microbial degradation in starch of sago frond. The role of microbe to degrade and convert starch into glucose may have been deactivated, which caused the reduction of sugars contents in the sap. During this study, the starch contents also analysed in order to investigate the cause of changes in sugar concentration during storage On the other side, the total reducing sugar in inner circle frond of Angkat punggung palm increased by $10 \%$. This could be due to the possible polymerize of sugar in young or adolescent fronds. According to Adeni et al. (2018), adolescent frond exhibited the highest cellulose content in the former. High cellulose content may be degraded by the microbe and convert into glucose (Kristiani et al., 2013).

Overall, the pattern of reducing sugar profile of most saps at different growth stages show a fluctuation after 21 days storage. The sugar concentration of all saps show a slight increase after few days before continue to decline until 21 days. In conclusion, it was clearly observed that the amount of reducing sugar in most of the samples obtained from two different growth stages decreased slightly from the original after 21 days of storage at $-20^{\circ} \mathrm{C}$.

Table 5. Total reducing sugar and percentage loss/gain of sago frond sap at different growth stages stages; Angkat punggung and Upong muda palm, stored at $-20^{\circ} \mathrm{C}$ within 21 days.

\begin{tabular}{|c|c|c|c|c|c|}
\hline \multicolumn{2}{|c|}{ Growth stages of frond } & \multicolumn{2}{|c|}{$\begin{array}{c}\text { Total Reducing Sugar } \\
(\mathrm{g} / \mathrm{L})\end{array}$} & \multirow{2}{*}{$\begin{array}{l}\text { Percentage } \\
\text { Loss }(\%)\end{array}$} & \multirow{2}{*}{$\begin{array}{c}\text { Percentage } \\
\text { Gain }(\%)\end{array}$} \\
\hline & & Day 0 & Day 21 & & \\
\hline \multirow{2}{*}{$\begin{array}{l}\text { Angkat punggung } \\
\text { (4-5 years) }\end{array}$} & Inner circle & $\begin{array}{c}37.52^{\mathrm{b}} \pm \\
0.3365\end{array}$ & $\begin{array}{c}41.34^{\mathrm{a}} \pm \\
0.3002\end{array}$ & - & 10.18 \\
\hline & Outer circle & $\begin{array}{c}32.43^{\mathrm{a}} \pm \\
0.5485\end{array}$ & $\begin{array}{c}21.29^{\mathrm{b}} \pm \\
0.2457\end{array}$ & 34.35 & - \\
\hline \multirow{2}{*}{$\begin{array}{l}\text { Upong muda } \\
\text { (6-7 years) }\end{array}$} & Inner circle & $\begin{array}{c}65.14^{\mathrm{a}} \pm \\
0.2004\end{array}$ & $\begin{array}{c}55.60^{\mathrm{b}} \pm \\
0.4092\end{array}$ & 14.65 & - \\
\hline & Outer circle & $\begin{array}{l}45.27^{\mathrm{a}} \pm \\
0.5105\end{array}$ & $\begin{array}{c}34.39^{\mathrm{b}} \pm \\
0.6220\end{array}$ & 24.03 & - \\
\hline
\end{tabular}

*(mean \pm standard error). Means that do not share a letter are significantly different at $\mathrm{p}<0.05$. 


\subsection{Effects of Storage on the Starch Content from Sago Frond Sap}

On the other side, the starch concentration of sago frond sap at two selected growth stages; Angkat punggung palm (inner and outer circle fronds) and Upong muda palm (inner and outer circle fronds) was analysed. The sap was kept at $-20^{\circ} \mathrm{C}$ during storage and analysed for every 48 hours within 2 days. The comparison of starch concentration and percentage loss in sago frond sap at different growth stages was presented in Table 6 .

Based on the result, it was observed that sap of outer circle frond from Upong muda palm shows the highest initial starch concentration during with an average of $1.21 \mathrm{~g} / \mathrm{L}$. Total starch content of all sap at different growth stages also decreased after 21 days of storage. Percentage loss of total starch content in Angkat punggung (outer and inner circle) and Upong muda (inner and outer circle) palm after storage are $12 \%, 36 \%, 33 \%$ and $15 \%$ respectively.
Similarly, the starch concentration profile of all saps steadily decreased after 21 days storage. It also shows that Upong muda palm contained higher starch composition compare to Angkat punggung palm. According to Zeeman et al. (2004), high starch content can be degraded into sugars such as glucose by the starch-degrading enzymes. However, the results in this study was contradict with the previous study as the starch degradation did not occurred within 21 days due to low presence of starch in the sap. Starch is likely to converted into glucose and other sugars but the process is interrupted due to various kinds of stresses, especially cold stress during long storage. It can be clearly observed in this study that the starch content is decreasing with the decreasing of sugar composition. Thus, it can be concluded that the low presence of starch in this study do not have much effect in the production of sugar content as not much difference can be observed in the patterns of sugar content of sago frond sap. Moreover, the amount of total starch content in all sap from different growth stages slightly decreased after 21 days storage and suitable for fermentation process without any modification.

Table 6. Total starch content and percentage loss of sago frond sap at different growth stages stages; Angkat punggung and Upong muda palm, stored at $-20^{\circ} \mathrm{C}$ within 21 days.

\section{Total Starch Content (g/L)}

\begin{tabular}{|c|c|c|c|c|}
\hline \multicolumn{2}{|c|}{ Growth stages of frond } & \multirow[b]{2}{*}{ Day 0} & \multirow[b]{2}{*}{ Day 21} & \multirow[t]{2}{*}{ Percentage Loss (\%) } \\
\hline & & & & \\
\hline \multirow{2}{*}{$\begin{array}{c}\text { Angkat punggung } \\
\text { (4-5 years) }\end{array}$} & Inner circle & $\begin{array}{c}0.3660^{\mathrm{a}} \pm \\
0.0051\end{array}$ & $\begin{array}{c}0.3225^{\mathrm{b}} \pm \\
0.0049\end{array}$ & 11.88 \\
\hline & Outer circle & $\begin{array}{c}0.7447^{\mathrm{a}} \pm \\
0.0077\end{array}$ & $\begin{array}{c}0.4750^{\mathrm{b}} \pm \\
0.0040\end{array}$ & 36.22 \\
\hline \multirow{2}{*}{$\begin{array}{l}\text { Upong muda } \\
\text { (6-7 years) }\end{array}$} & Inner circle & $\begin{array}{c}1.046^{\mathrm{a}} \pm \\
0.0047\end{array}$ & $\begin{array}{c}0.7014^{\mathrm{b}} \pm \\
0.0170\end{array}$ & 32.94 \\
\hline & Outer circle & $\begin{array}{c}1.2077^{\mathrm{a}} \pm \\
0.0213\end{array}$ & $\begin{array}{c}1.0323^{\mathrm{b}} \pm \\
0.0038\end{array}$ & 14.52 \\
\hline
\end{tabular}

\footnotetext{
*(mean \pm standard error). Means that do not share a letter are significantly different at $\mathrm{p}<0.05$.
} 


\section{CONCLUSION}

In conclusion, the characterisation (volume, biochemical contents) of frond sap from two selected growth stages (Angkat punggung and Upong muda) and different positions within the rosette (inner and outer circle) of the sago palm was studied. It can be concluded that outer circle frond of Upong muda palm extracted the largest volume of sago frond sap from $1 \mathrm{~kg}$ and one frond. The results indicated that sago frond sap has an acidic $\mathrm{pH}$, with glucose as dominant sugar component and contained various kinds of minerals like calcium, potassium, manganese and magnesium. High amount of fermentable sugars (glucose and xylose) in the frond sap is useful in bioethanol, lactic acid and xylitol fermentation. Furthermore, sap extracted from inner circle frond of Upong muda palm gave the highest reducing sugar with low starch content compared to other fronds during storage at $-20^{\circ} \mathrm{C}$. After 21 days of storage, the amount of reducing sugars and starch in most of the samples obtained from two different growth stages decreased slightly from the original. Thus, this study showed that both fresh and stored frond sap is suitable as a fermentation substrate without any modification. Sago frond sap is suitable substrate for economical bioconversion into by-products because no additional chemical, enzymatic process or pre-treatment with low cost and excellent contents of sugars, minerals properties.

\section{ACKNOWLEDGEMENT}

This research was supported by Kementerian Pengajian Tinggi Malaysia, Fundamental Research Grant Scheme, FRGS/1/2017/STG05/UNIMAS/01/1.

\section{REFERENCES}

Adeni, D.S. A., Ahmad, M. N., \& Bujang, K. B. (2018). Maximising production of prebiotic sugar (cellobiose) from sago frond. Malaysian Applied Biology Journal, 47 (1): 89-95.

Ahmad, M. N., Bujang, K. B., \& Adeni, D. S. A. (2016). Cellobiose from sago frond. $9^{\text {th }}$ UNIMAS Research and Development Expo 2016. Kota Samarahan, Sarawak: Universiti Malaysia Sarawak.

Bujang, K. B. (2014). Sago: A food and fuel alternative. Bioborneo 2014. Kuching, Sarawak: Sarawak Biodiversity Centre.

Department of Statistic Malaysia. (2012). Department of Agriculture Malaysia, Sarawak Branch. Report on Sago Export 2002- 2011, (pp. 4-5).

Department of Statistic Malaysia. (2015). Estimated area of sago by district 2009-2013. Page number 28-31. Retrieved December 24, 2015, from https://www.statistics.gov.my

Flach, M. (1997). Sago palm. Metroxylon sagu Rottb: Promoting the conservation and use of underutilized and neglected crops. Rome. Italy: International Plant Genetic Resource Institute.

Jong, F. S. (1995). Research for the development of sago palm (Metroxylon sagu Rottb.) cultivation in Sarawak, Malaysia. PhD thesis, Wageningen Agricultural University, the Netherlands, Jong Foh-Shoon, Department of Agriculture, Kuching, Sarawak, Malaysia. 
Kosugi, A., Tanaka, R., Magara, K., Murata, Y., Arai, T., Sulaiman, O., ... Mori, Y. (2010). Ethanol and lactic acid production using sap squeezed from oil palm trunks felled for replanting. Journal of Bioscience and Bioengineering, 110 (3): 322-5.

Kristiani, A., Abimanyu, H., Setiawan, A. H., Sudiyarmanto, \& Aulia, F. (2013). Effect of pretreatment process by using diluted acid to characteristic of oil palm frond. Energy Procedia, 32: 183-189.

Miller, G. L. (1959). Use of dinitrosalicylic acid reagent for determination of reducing sugar. Analytical Chemistry,31 (3): 426-428.

Mohamad, R., Mohamed, M. S., Suhaili, N., Salleh, M. M., \& Arif, A. (2010). Kojic Acid: Applications and development of fermentation process for Production. Biotechnology and Molecular Biology Reviews, 5 (2): 24-37.

Nakamura, L. K. (1981). Lactobacillus amylovorus, a new starch-hydrolyzing species from cattle waste corn fermentation. International Journal of System Bacteriology, 31: 56-63.
Russell, I. (2003). Understanding Yeast Fundamentals. In The Alcohol Textbook: A reference for the beverage, fuel and industrial alcohol industries: (Jacques, K. A., Lyons, T. P., \& Kelsall, D. R., ed.), pp. 85-120. Nottingham: University Press.

Singh, S., Gaikwad, K. \& More, P. K. (2014). Spoilage of sugarcane juice: A problem in sugarcane industry. International Journal of Agricultural Engineering, 7 (1): 259-263.

Zahari, M. A. K., Zakaria, M. R., Ariffin, H., Mokhtar, M. N., Salihon, J., Shirai, Y. \& Hassan, M. A. (2012). Renewable sugars from oil palm frond juice as an alternative: Novel fermentation feedstock for value-added products. Bioresource Technology, 110: 566571.

Zeeman, S. C., Smith, S. M., \& Smith, A. M. (2004). The breakdown of starch in leaves. New Phytologist, 163: 247-26. 